\title{
MOISTURE SORPTION ISOTHERMS OF QUINOA SEEDS: THERMODYNAMIC ANALYSIS
}

\author{
Jaime D. Bustos-Vanegas ${ }^{1 *}$, Paulo C. Corrêa ${ }^{2}$, Juliana S. Zeymer², Fernanda M. Baptestini' ${ }^{3}$, \\ Renata C. Campos ${ }^{2}$
}

${ }^{1 *}$ Corresponding author. Universidade Federal de Viçosa/ Viçosa - MG, Brasil. E-mail: jdbustosv@gmail.com

\author{
KEYWORDS \\ entropy, Gibbs \\ energy, hysteresis, \\ isosteric heat, \\ mathematical \\ modeling.
}

\begin{abstract}
The present research aimed to study the water sorption behavior of quinoa seeds analyzing the hysteresis phenomenon and determining thermodynamic properties. Static gravimetric technique was used to obtain the equilibrium moisture content of quinoa seeds in different temperature conditions $\left(15,25,35\right.$ e $\left.50{ }^{\circ} \mathrm{C}\right)$ and relative humidity (between 11 and 96\%). Equilibrium moisture content data were adjusted by eight mathematical models and the Modified Halsey model was the best one to describe the water sorption phenomena of quinoa seeds. Hygroscopic equilibrium moisture content of quinoa seeds is directly proportional to the water activity and decreases with increasing temperature. The hysteresis phenomena were observed throughout the range of water activity, showing more evident at low temperatures. Integral isosteric heat and differential entropy decreased with the increase of equilibrium moisture content. Gibbs free energy decreased with the increase of temperature and equilibrium moisture content. Compensation enthalpyentropy theory was confirmed and the sorption mechanism is controlled by enthalpy.
\end{abstract}

\section{INTRODUCTION}

Quinoa (Chenopodium quinoa Willd.) is a pseudocereal cultivated in the Andean region for more than 7.000 years (Vega-Gálvez et al., 2010) and explored for food and feed. The protein content of quinoa is higher than other cereals, ranging from 15 to $17.5 \%$ (Stikic et al., 2012). In particular, its amino acid composition is considered to be close to ideal, as recommended by Food and Agriculture Organization of the United Nations - FAO. In addition, the physical-chemical stability of its starch gives functional properties (James, 2009) and greater storage potential than oilseeds.

These seeds have a considerable porosity in the outer layer, providing moisture loss or gain easily (Spehar, 2007). Since they are highly hygroscopic, the water content of the seeds is constantly influenced by the relative humidity of the air around them, and therefore they are always seeking hygroscopic equilibrium (Corrêa et al., 2005).

The sorption isotherms (adsorption and desorption) are defined as a relationship between the total moisture content and the water activity in the food at the constant temperature. The knowledge basis of the adsorption and desorption isotherms is useful to ensure adequate storage conditions and to understand the phenomenon of hysteresis. The desorption isotherms have higher equilibrium moisture values than the adsorption isotherms at a given water activity. The lag between these two curves is called hysteresis (Wolf et al., 1972).

Water activity is one of the variables that most affect the metabolic processes in agricultural products (Souza et al., 2015). Consequently, the control of this variable during storage is of vital importance to ensure product stability. The present research had as main objective to study the mathematical modeling of water sorption isotherms of quinoa seeds in different conditions of temperature and relative humidity; investigate the alterations in thermodynamic properties (integral isosteric heat of sorption, differential entropy, Gibbs free energy, and enthalpy-entropy compensation theory) of sorption processes; and analyze the hysteresis phenomenon, aiming to provide information that allows planning of storage systems that guarantee the quality of the product stock.

\footnotetext{
${ }^{2}$ Universidade Federal de Viçosa/ Viçosa - MG, Brasil.

${ }^{3}$ Universidade Federal do Espírito Santo/ Alegre - ES, Brasil.

Received in: 9-4-2017

Accepted in: 7-25-2018
} 


\section{MATERIAL AND METHODS}

The current study was developed in the Laboratory of Physical Properties and Quality Assessment of Agricultural Products belonging to the National Training Center in Storage (CENTREINAR), located at the Federal University of Viçosa, Viçosa, MG.

Quinoa (Chenopodium quinoa Willd) seeds were purchased in the local Viçosa/MG market. In order to obtain the equilibrium moisture content of quinoa seeds by desorption and adsorption processes, the static-gravimetric method was employed (Brasil, 2009). Different temperature conditions $\left(15,25,35\right.$ and $\left.50{ }^{\circ} \mathrm{C}\right)$ and relative humidity (between 11 and 96\%) were used until the product reached the equilibrium moisture content with the condition of the specified air.

Quinoa seeds with 8.13\% (d.b.) of moisture content were used to analyze the desorption process. For the adsorption processes, part of the seeds was dried in a forced air circulation oven at $60{ }^{\circ} \mathrm{C}$ until reached $2.5 \%$ (d.b.) of moisture content. Moisture content was obtained by gravimetry using an oven (New Ethics 400-3ND Model) at
$105{ }^{\circ} \mathrm{C}$ for $24 \mathrm{~h}$. For the weighing, an analytical balance (Marte AY220 Model) with accuracy of $0.001 \mathrm{~g}$ and resolution of $0.0001 \mathrm{~g}$ was used.

The relative air humidity was controlled using saturated aqueous solutions from different salts, in which they were deposited in sealed glass containers of $2000 \mathrm{~mL}$, containing samples of the product in strainers, above the surface of the solution. The samples with approximately 15 $\mathrm{g}$ of seeds were placed in chambers (incubator) like B.O.D. (model $347 \mathrm{CD} / \mathrm{brand}$ Fanem) corresponding to each desired temperature, in three replicates.

The product was weighed in analytical balance (model AY220/brand Marte) with predetermined time intervals until hygroscopic equilibrium, where the partial water vapor pressure of the product is equal to partial vapor pressure from air ambient where the samples are conditioned.

Mathematical models frequently used to represent the hygroscopicity of agricultural products was adjusted to the experimental data of equilibrium moisture content. The expressions are shown in Table 1.

TABLE 1. Mathematical models used to predict sorption isotherms

\begin{tabular}{cc}
\hline Model & Equation \\
\hline Modified Oswin (Oswin, 1946) & $U_{e}=\frac{a+b T}{\left[\frac{\left(1-a_{w}\right.}{a_{w}}\right]^{1 / c}}$ \\
Modified Halsey (Iglesias \& Chirife, 1976) & $U_{e}=\left[\frac{\exp (a-b T)}{-\ln a_{w}}\right]^{1 / c}$ \\
Modified GAB (Anderson, 1946) & $\begin{array}{c}a b\left(\frac{c}{T}\right) a_{w} \\
\text { Copace (Corrêa \& Almeida, 1999) }\end{array}$ \\
Sigma-Copace (Teixeira et al., 2015) & $U_{e}=\exp \left[a-(b T)+\left(c a_{w}\right)\right]$ \\
Henderson (Resende et al., 2006) & $U_{e}=\exp \left[a-(b T)+\left(c \exp \left(a_{w}\right)\right)\right]$ \\
Henderson-Thompson (Thompson et al., 1968) & $U_{e}=\left[\frac{\ln \left(1-a_{w}\right)}{[-a(T+273.15)]}\right]^{1 / c}$ \\
Smith (Corrêa et al., 2006) & $U_{e}=\left[\frac{\ln \left(1-a_{w}\right)}{[-a(T+b)]}\right]^{1 / c}$ \\
\hline
\end{tabular}

In which:

$\mathrm{U}_{\mathrm{e}}$ - equilibrium water content, \% d.b.;

$\mathrm{a}_{\mathrm{w}}-$ water activity, decimal,

$\mathrm{T}$ - temperature, at ${ }^{\circ} \mathrm{C} ; \mathrm{a}, \mathrm{b}, \mathrm{c}, \mathrm{d}$ - coefficients of the models. 
Thermodynamic properties of quinoa seeds were obtained by the method described by Corrêa et al. (2012) as expressed by Equations 9 to 13 .

$$
\begin{aligned}
& \ln \left(a_{w}\right)= \pm\left(\frac{\Delta h_{s t}}{R T_{a}}-\frac{\Delta S}{R}\right) \\
& Q_{s t}=\Delta h_{s t}+L \\
& \Delta G= \pm R T_{a} \ln \left(a_{w}\right) \\
& T_{h m}=\frac{n}{\sum_{i=1}^{n}\left(\frac{1}{T_{a}}\right)} \\
& T_{B}=\widehat{T}_{B} \pm t_{\left(m-2, \frac{\alpha}{2}\right)} \sqrt{\operatorname{Var}\left(T_{B}\right)}
\end{aligned}
$$

In which:

$\mathrm{a}_{\mathrm{w}}$ - water activity, decimal;

$\mathrm{R}$ - universal gas constant, $8.314 \mathrm{~J} \mathrm{~mol}^{-1} \mathrm{~K}^{-1}$;

$\mathrm{T}_{\mathrm{a}}$ - absolute temperature, $\mathrm{K}$;

$\Delta \mathrm{h}_{\mathrm{st}}$ - isosteric liquid sorption heat, $\mathrm{kJ} \mathrm{kg}^{-1}$;

$\mathrm{L}$ - Latent heat of vaporization of free water, $\mathrm{kJ} \mathrm{kg}^{-1}$;

$\mathrm{Q}_{\mathrm{st}}$ - full isosteric heat of sorption, $\mathrm{kJ} \mathrm{kg}^{-1}$;

$\Delta \mathrm{S}$ - Entropy differential sorption, $\mathrm{kJ} \mathrm{kg}^{-1} \mathrm{~K}^{-1}$;

$\Delta \mathrm{G}-$ Gibbs free energy, $\mathrm{kJ} \mathrm{kg}^{-1}$;

$\mathrm{T}_{\mathrm{B}}$ - isokinetic temperature, $\mathrm{K}$;

$\mathrm{T}_{\mathrm{hm}}$ - harmonic mean temperature, $\mathrm{K}$;

$\mathrm{n}$ - number of temperatures used,

$\mathrm{m}-$ number of enthalpy and entropy data pairs.
The adjustment of the mathematical models was performed by non-linear regression by Gauss-Newton method, using the software Statistica $7.0^{\circledR}$. In selecting the best model to predict the equilibrium moisture content, was calculated the magnitudes of the standard deviation of the estimate (SDE) (Eq. 14), mean relative error (MRE) (Eq. 15), determination coefficient $\left(\mathrm{R}^{2}\right)$ and residual distribution. For a good mathematical adjustment, MRE must be less than $10 \%$ (Costa et al., 2015), $\mathrm{R}^{2}$ near unity (Kashaninejad et al., 2007), SDE close to zero (Draper \& Smith, 1998), and residues randomly distributed (Alves et al., 2013; Corrêa et al., 2014).

$$
\begin{aligned}
& S D E=\sqrt{\frac{\sum_{i=1}^{n}\left(Y_{i}-\hat{Y}_{i}\right)^{2}}{G L R}} \\
& M R E=\frac{100}{n} \sum_{i=1}^{n} \frac{\left|Y_{i}-\hat{Y}_{i}\right|}{Y_{i}}
\end{aligned}
$$

In which:

$$
\begin{aligned}
& \mathrm{Y}_{\mathrm{i}} \text { - value observed experimentally; } \\
& \hat{\mathrm{Y}}_{\mathrm{i}} \text { - value estimated by the model; } \\
& \mathrm{n} \text { - number of observed data, }
\end{aligned}
$$

\begin{tabular}{|c|c|c|c|c|c|c|c|}
\hline \multirow{2}{*}{ Model } & \multicolumn{3}{|c|}{ Parameters } & \multirow{2}{*}{$\mathrm{R}^{2}(\%)$} & \multirow{2}{*}{$\begin{array}{c}\text { SDE } \\
(\% \text { d.b. })\end{array}$} & \multirow{2}{*}{$\operatorname{MRE}(\%)$} & \multirow{2}{*}{ Residual Distribution } \\
\hline & $\mathrm{a}$ & $\mathrm{b}$ & $\mathrm{c}$ & & & & \\
\hline Oswin Modified & 15.06278 & -0.1436 & 3.01422 & 98.75 & 0.04 & 10.73 & Biased \\
\hline Halsey Modified & 5.6083 & -0.0317 & 2.1514 & 98.96 & 0,03 & 7.98 & Random \\
\hline GAB Modified & 6.6989 & 0.8359 & 465.3184 & 97.94 & 1.98 & 13.13 & Random \\
\hline Copace & 1.2677 & 0.0077 & 2.5143 & 96.63 & 2.52 & 15.10 & Biased \\
\hline Sigma-Copace & 0.3802 & 0.0080 & 1.2833 & 97.34 & 1.99 & 9.85 & Random \\
\hline Henderson & 0.000075 & 1.4195 & - & 97.05 & 2.36 & 15.35 & Biased \\
\hline $\begin{array}{c}\text { Henderson- } \\
\text { Thompson }\end{array}$ & 0.00027 & 56.3612 & 1.4232 & 97.69 & 2.09 & 13.93 & Biased \\
\hline Smith & 8.9201 & 0.1481 & 9.0100 & 98.66 & 1.49 & 8.45 & Biased \\
\hline
\end{tabular}

GLR - residual degrees of freedom (number of observed data minus the number of model parameters).

\section{RESULTS AND DISCUSSION}

The values of the parameters of the different hygroscopic equilibrium models fitted to the experimental data are shown in Tables 2 and 3 .

TABLE 2. Parameters of hygroscopic equilibrium models for the desorption of quinoa seeds, with their respective: determination coefficients $\left(\mathrm{R}^{2}\right)$, standard deviation of the estimate (SDE), mean relative error (MRE) and analysis of residual distribution. 
TABLE 3. Parameters of hygroscopic equilibrium models for the adsorption of quinoa seeds, with their respective: determination coefficients $\left(\mathrm{R}^{2}\right)$, standard deviation of the estimate (SDE), mean relative error (MRE) and analysis of residual distribution.

\begin{tabular}{|c|c|c|c|c|c|c|c|}
\hline \multirow{2}{*}{ Model } & \multicolumn{3}{|c|}{ Parameters } & \multirow{2}{*}{$\mathrm{R}^{2}(\%)$} & \multirow{2}{*}{$\begin{array}{c}\text { SDE } \\
(\% \text { d.b. })\end{array}$} & \multirow{2}{*}{$\operatorname{MRE}(\%)$} & \multirow{2}{*}{ Residual Distribution } \\
\hline & $\mathrm{a}$ & $\mathrm{b}$ & $\mathrm{c}$ & & & & \\
\hline Oswin Modified & 12.0144 & -0.10487 & 2.81209 & 97.28 & 0.05 & 10.81 & Biased \\
\hline Halsey Modified & 4.9313 & -0.0275 & 2.0866 & 97.98 & 0.04 & 8.44 & Random \\
\hline GAB Modified & 5.1515 & 0.8806 & 723.4795 & 97.83 & 1.82 & 12.15 & Random \\
\hline Copace & 0.7423 & 0.0066 & 3.0135 & 96.81 & 2.44 & 19.82 & Biased \\
\hline Sigma-Copace & 0.1949 & 0.0068 & 1.4829 & 97.85 & 1.90 & 11.85 & Random \\
\hline Henderson & 0.000172 & 0.1868 & - & 97.13 & 2.31 & 18.72 & Biased \\
\hline Henderson-Thompson & 0.00044 & 89.6080 & 1.1879 & 97.43 & 2.19 & 18.37 & Biased \\
\hline Smith & 5,2673 & 0.1033 & 9.4625 & 98.00 & 1.93 & 14.03 & Biased \\
\hline
\end{tabular}

Analyzing Tables 2 and 3, it is observed that among the eight models tested, the Modified Halsey model was the most suitable to describe the desorption and adsorption phenomenon of the quinoa seeds, since the statistical parameters are in agreement with which is advocated by several researchers (Resende et al., 2014; Chaves et al., 2015; Sousa et al., 2015), such as, high coefficient of determination $\left(\mathrm{R}^{2}\right)$, mean relative error (MRE) until $10 \%$, standard deviation of the estimate (SDE) reduced and

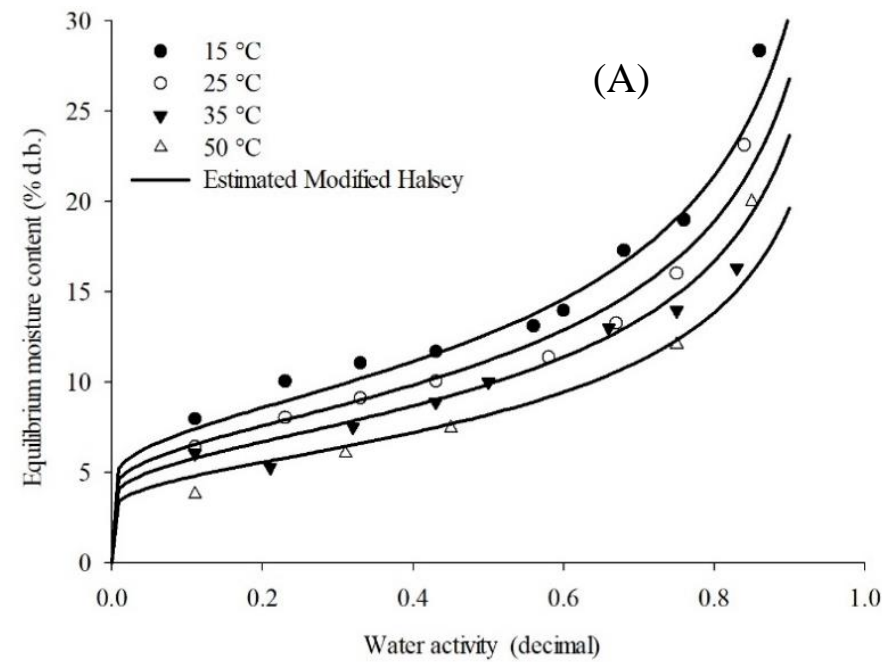

aleatory residual distribution. These results are similar to those found by Goneli et al. (2016), who also recommended the Modified Halsey model for the representation of the equilibrium moisture content, by desorption and adsorption, of castor beans.

The observed equilibrium moisture content data of quinoa seeds obtained by desorption and adsorptions, as well as their isotherms determined by the Modified Halsey model are shown in Figure 1.

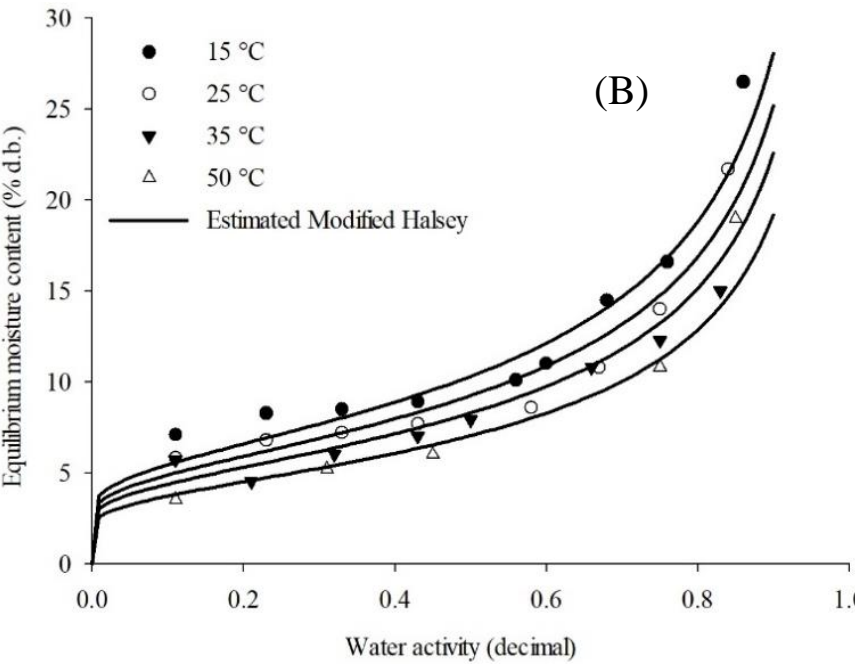

FIGURE 1. Values observed and estimated by the Modified Halsey model of the equilibrium water content of quinoa seeds obtained by desorption (A) and adsorption (B)

It can be observed that there is correspondence between the data estimated by the Modified Halsey model and experimental data. In both process (desorption and adsorption), the equilibrium moisture content of quinoa seeds is directly proportional to the water activity and decreases with increasing temperature, indicating low hygroscopicity of the material at high temperatures. Palipane \& Driscoll (1992) complement that with the increase in temperature, the water molecules reach higher energy levels, becoming thermodynamically less stable, favoring the breaking of the connection between the water and the sorption sites, and thus reducing the moisture content of the product.

The isothermal curves showed a sigmoidal behavior, characteristic of type II curve, according to the classification of Brunauer et al. (1940). Several authors also observed the same behavior in yam flour, jatropha seeds, corn beans, turnip seeds, crambe fruits, mucilage from chia seeds, orange powder, preckly pear and Lactuta sativa seeds (Siqueira et al., 2012; Smaniotto et al., 2012; Sousa et al., 2013; Costa et al., 2013; Hassini et al., 2015; VelázquezGutiérrez et al., 2015; Sormoli \& Langrish, 2015; Solomon \& Zewdu, 2016; Zeymer et al., 2017).

Another relevant observation that can be made when comparing the generated isotherms is that, for all air conditions used, the values of hygroscopic equilibrium moisture content obtained by desorption were always higher than those obtained by adsorption, evidencing the phenomenon of hysteresis (Figure 2). These results are in agreement with Goneli et al. (2013) studying sorption of water from coffee fruits, Souza et al. (2015) studying mango skin hysteresis and Campos et al. (2016) studying the hysteresis of bean grains. 

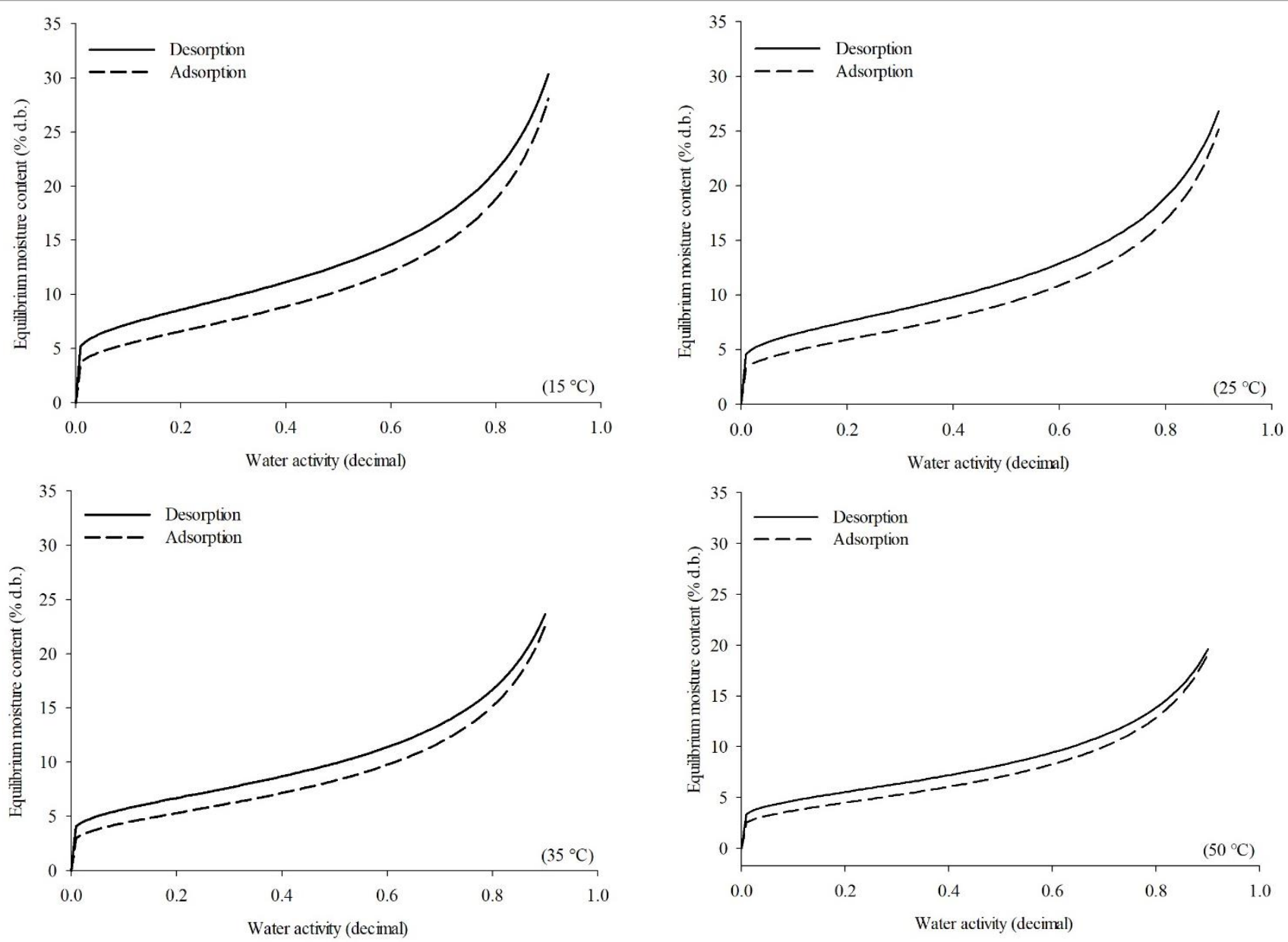

FIGURE 2. Estimation of desorption and adsorption isotherms of quinoa seeds, for all temperatures studied, evidencing the phenomenon of hysteresis

The phenomenon of hysteresis is explained by several authors. According to Lahsasni et al. (2004), during the adsorption, the pore capillary of the grains begins to fill as a consequence of the increase of the relative humidity. When the partial pressure of water vapor from the air becomes higher than the vapor pressure in the capillary, the water moves into the pore. In desorption the pore is initially saturated. The diffusion of water from the periphery to the grain surface occurs only when the partial vapor pressure of the surrounding air becomes smaller than the vapor pressure inside the capillary. In addition, the same authors state that the differences between adsorption and desorption occur due to the wide variety of capillary diameters in the grain pore system. In Figure 2 it can be noticed the temperature dependence on the hysteresis phenomena of quinoa seeds.

Analyzing Figure 2, it can be seen that the hysteresis (desorption equilibrium moisture content less moisture content of the adsorption) was more pronounced at lower temperatures, besides being observed throughout the water activity range, as verified by several authors (Bejar et al., 2012; Corrêa et al., 2014; Koua et al., 2014; Souza et al., 2015; Goneli et al., 2016) in orange peel, coffee fruits, cassava, turnip seeds and castor beans.

The dependence of the integral isosteric heat of sorption of quinoa seeds on the equilibrium moisture content is shown in Figure 3. 

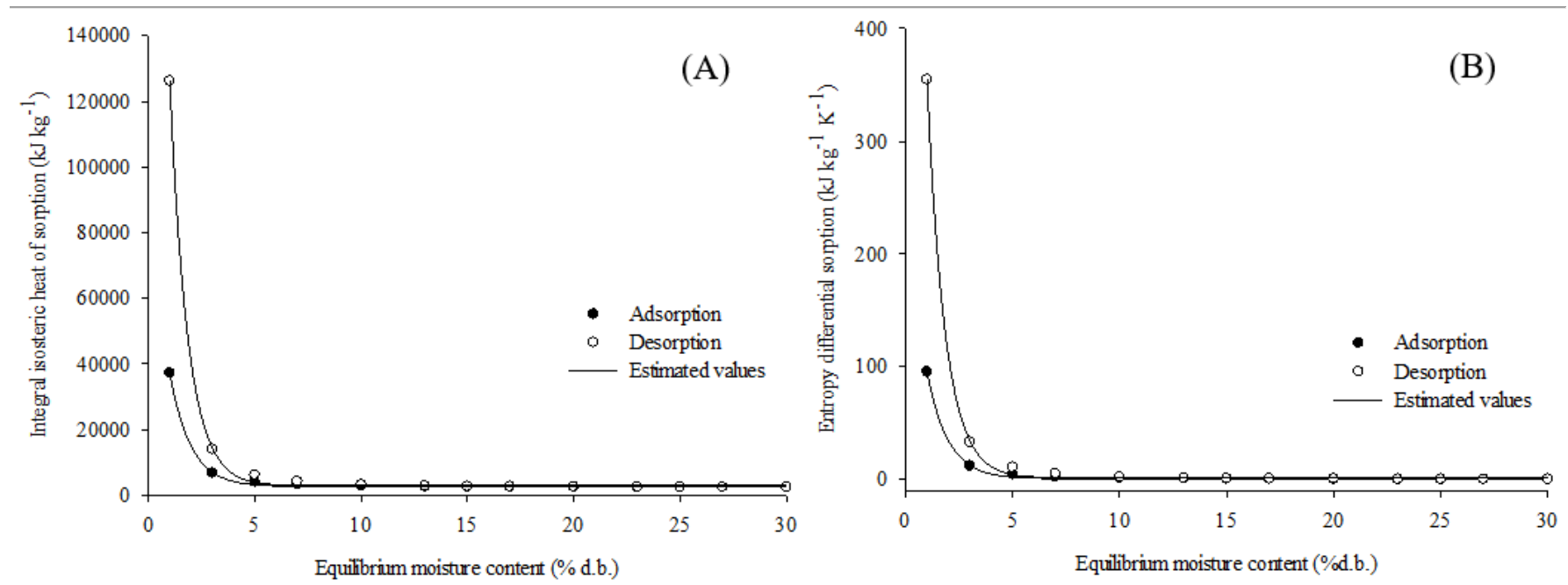

FIGURE 3. Integral isosteric heat of sorption (A) and differential entropy sorption (B) of the quinoa seeds a function of equilibrium moisture content

The results show a progressive increase in heat sorption at low moisture content. Bonner \& Kenney (2013) stated that this occur because in the initial phase of sorption, there are high active polar sites on the surface of the product, which are covered by water molecules forming the monolayer. It results in stronger water-solid interactions.

It can be observed that the values of the integral isosteric heat of desorption process of the quinoa seeds were higher than the values of the integral isosteric heat of adsorption; however, the values tend to a common equilibrium value at higher moisture contents (Figure 3A). This trend indicates that desorption process requires lower energy in order to occur than adsorption process. These results support the findings of Bonner \& Kenney (2013) and Corrêa et al. (2017).

The differential entropy of sorption (Figure 3B) showed the same pattern as the integral isosteric heat of sorption. It is known that the entropy of a material is proportional to the number of sorption sites available at a specific energy level, which gives an indication of the state of water molecules mobility. Therefore, the water molecules showed increased mobility in the desorption process than in the adsorption process. The same result was reported by Goneli et al. (2010) in millet grains. Moreover, the differential entropy tends to decrease to a constant value at high equilibrium moisture content, indicating that the sorption process may be reversible to some value (Madamba et al., 1996).

Table 4 lists the equations adjusted to the experimental data of the isosteric heat and the differential entropy of sorption of the quinoa seeds obtained by desorption and adsorption. It can be noticed that the equations are suitable to predict the phenomena as the $\mathrm{R}^{2}$ coefficients are greater than $99 \%$ and the regression coefficients shows statistical significance.

TABLE 4. Equations adjusted to the experimental data of the integral isosteric heat and differential entropy of sorption of the quinoa seeds obtained by desorption and adsorption.

\begin{tabular}{ccc}
\hline Identification & Adjusted equation & $\mathrm{R}^{2}(\%)$ \\
\hline Adsorption & $Q_{s t}=2686.6314^{*}+96824.9367^{*} * \exp \left(-1.0296^{*} * U_{e}\right)$ & 99.87 \\
& $\Delta S=0.7110^{* *}+265.6857^{*} * \exp \left(-1.0296^{*} * U_{e}\right)$ & 99.87 \\
Desorption & $Q_{s t}=2954.3655^{*}+403298^{*} * \exp \left(-1.1858^{*} * U_{e}\right)$ & 99.94 \\
& $\Delta S=1.5105^{*}+1156.2267^{*} * \exp \left(-1.1858^{*} * U_{e}\right)$ & 99.94 \\
\hline
\end{tabular}

* Significant at $1 \%$ probability by $\mathrm{t}$ test.

** Significant at $1 \%$ probability by $\mathrm{t}$ test. 

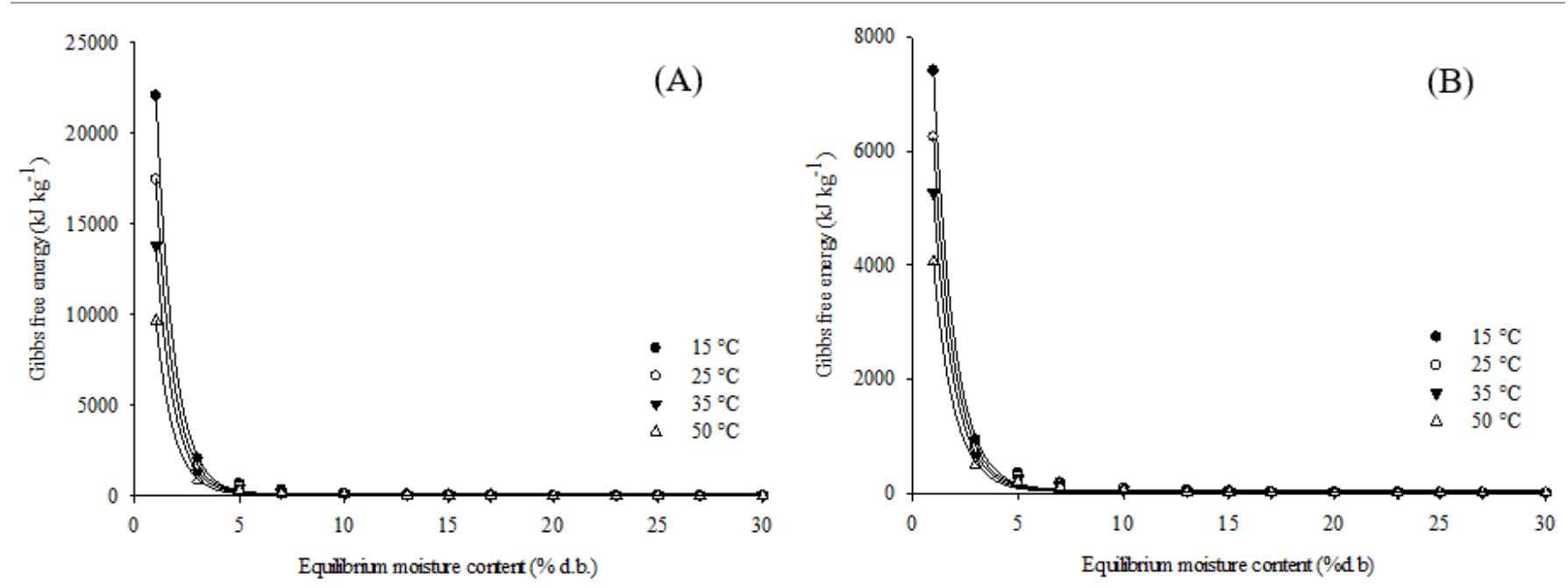

FIGURE 4. Gibbs free energy of quinoa seeds obtained by desorption (A) and adsorption (B).

The Gibbs free energy is a thermodynamic function that represents the maximum amount of energy released in a process at constant temperature and pressure, which is available to be used. It is the balance between enthalpy and entropy. The effect of a change in water sorption in Gibbs free energy is generally accompanied by changes in enthalpy and entropy (Telis-Romero et al., 2005). Gibbs free energy decreased with increase in temperature and equilibrium moisture content, and in the latter case, it tends to a constant value. This behavior was also observed in previous studies by Kaleemullah \& Kailappan (2007), Oliveira et al. (2014) and Sousa et al. (2015). From Figure 4 , it can be observed that Gibbs free energy in the desorption process was higher compared to the adsorption process at temperatures of $15,25,35$ and $40{ }^{\circ} \mathrm{C}$, similar to results obtained by Kaleemullah \& Kailappan (2007).

Figure 5 illustrates the enthalpy-entropy relationship with the water sorption process of the quinoa seeds.

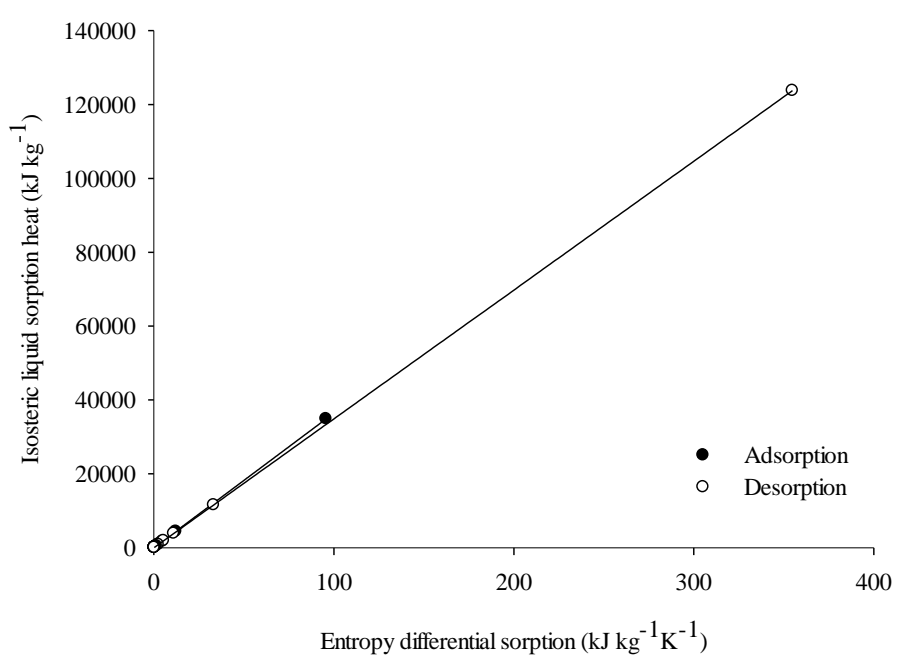

FIGURE 5. Compensation enthalpy-entropy of the sorption process of the quinoa seeds.

It was observed that a strong correlation exists between the two thermodynamic properties (enthalpy and entropy). However, only the difference between the harmonic mean temperature $\left(\mathrm{T}_{\mathrm{hm}}\right)$ and the isokinetic temperature $\left(\mathrm{T}_{\mathrm{B}}\right)$ may indicate that such relationship exists (enthalpy-entropy compensation theory). $\mathrm{T}_{\mathrm{hm}}$ was $303.86 \mathrm{~K}$ and the $\mathrm{T}_{\mathrm{B}}$ values are listed in Table 5 , thereby confirming the chemically linear compensation. Furthermore, as $T_{B}$ values were higher than $T_{h m}$, it can be concluded that the sorption mechanism is controlled by the enthalpy (Corrêa et al., 2012). Previous studies also made the conclusion that sorption was controlled by the enthalpy (Goneli et al., 2013; Corrêa et al., 2015, 2017).
TABLE 5. Isokinetic temperature and Gibbs free energy at the isokinetic temperature of the quinoa seeds obtained by desorption and adsorption.

\begin{tabular}{cccc}
\hline Identification & $\mathrm{T}_{\mathrm{B}}(\mathrm{K})$ & $\Delta \mathrm{G}_{\mathrm{B}}\left(\mathrm{kJ} \mathrm{kg}^{-1}\right)$ & $\mathrm{R}^{2}(\%)$ \\
\hline Adsorption & 364.43 & $1.214 * 10^{-13}$ & 99.99 \\
Desorption & 348.81 & $6.366 * 10^{-12}$ & 99.99 \\
\hline
\end{tabular}

\section{CONCLUSIONS}

The hygroscopic equilibrium moisture content of quinoa seeds is directly proportional to the water activity and decreases with increasing temperature;

The Modified Halsey model is the best one to represents desorption and adsorption isotherms of quinoa seeds when compared to other models tested; 
The hysteresis phenomenon is observed throughout the range of water activity, and its magnitude is reduced with the elevation of temperature;

Exponential models were adjusted to the integral isosteric heat data and the differential entropy of sorption as a function of the equilibrium moisture;

Integral isosteric heat and differential entropy decreased with the increase of equilibrium moisture content;

Gibbs free energy decreased with the increase of temperature and equilibrium moisture content;

Compensation enthalpy-entropy theory was confirmed and it can be concluded that the sorption mechanism is controlled by enthalpy.

\section{ACKNOWLEDGMENTS}

The authors would like to thank the Conselho Nacional de Desenvolvimento Científico Tecnológico (CNPq) and Fundação de Amparo à Pesquisa do Estado de Minas Gerais (FAPEMIG) for providing funding for this research.

\section{REFERENCES}

Alves GE, Isquierdo EP, Borém FM, Siqueira VC, Oliveira PD, Andrade ET (2013) Cinética de secagem de café natural para diferentes temperaturas e baixa umidade relativa. Coffee Science 8(2):238-247.

Anderson RB (1946) Modifications of the B.E.T. equation. Journal of American Chemical Society (68):686-691.

Bejar AK, Boudhrioua NM, Kechaou N (2012) Moisture sorption isotherms - experimental and mathematical investigations of orange (Citrus sinensis) peel and leaves. Journal Food Chemistry 132(4):1728-1735. DOI: https://doi.org/10.1016/j.foodchem.2011.06.059

Bonner IJ, Kenney KL (2013) Moisture sorption characteristics and modeling of energy sorghum (Sorghum bicolor (L) Moench). Journal of Stored Products Research 52:128-136. DOI: https://

doi.org/10.1016/j.jspr.2012.11.002

Brasil. Ministério da Agricultura e Reforma Agrária (2009) Regras para análise de sementes. Brasília, Secretaria Nacional de Defesa Agropecuária, 395 p.

Brunauer S, Deming LS, Teller E (1940) On a theory of Van der Waals adsorption of gases. Journal of the American Chemical Society 62(7):1723-1732. DOI: https:// doi.org/10.1021/ja01864a025

Campos RC, Corrêa PC, Fernandes LS, Baptestini, FM, Costa CF, Bustos-Vanegas JD (2016) Bean grain hysteresis with induced mechanical damage. Revista Brasileira de Engenharia Agrícola e Ambiental 20(10):930-936. DOI: http://doi.org/10.1590/18071929/agriambi.v20n10p930-935

Chaves TH, Resende O, Oliveira DEC, Smaniotto TAS, Sousa KA (2015) Isotermas e calor isostérico das sementes de pinhão-manso. Engenharia na Agricultura 23(1):9-18. DOI: http://doi.org/10.13083/1414-3984/reveng.v23n1p9-18

Corrêa PC, Almeida FAC (1999) Comparação de modelos matemáticos de equilíbrio higroscópico para semente e fibra de algodão herbáceo, cultivar Redenção. Revista de Oleaginosas e Fibrosas 3(1):1-6.
Corrêa PC, Goneli ALD, Resende O, Ribeiro DM (2005) Obtenção e modelagem das isotermas de dessorção e do calor esotérico de dessorção para grãos de trigo. Revista Brasileira de Produtos Agroindustriais 7(1):39-48. DOI: http://dx.doi. org/10.15871/1517-8595/rbpa.v7n1p39-48

Corrêa PC, Afonso Júnior PC, Ribeiro DM, Silva FS (2006) Equilíbrio higroscópico de milheto, alpiste e painço: Obtenção e modelagem 10(1):162-167.

Corrêa PC, Oliveira GHH, Santos ES (2012)

Thermodynamic properties of agricultural products processes. In: Arana, I. Physical properties of foods: Novel measurement techniques and applications. Boca Raton, CRC Press, p131-142.

Corrêa PC, Botelho FM, Botelho SCC, Goneli ALD (2014) Isotermas de sorção de água de frutos de Coffea canephora. Revista Brasileira de Engenharia Agrícola e Ambiental 18(10):1047-1052. DOI:

http://doi.org/10.1590/1807-1929/agriambi.v18n10p10471052

Corrêa PC, Reis MFT, Oliveira GHH de, Oliveira APLR, Botelho FM (2015) Moisture desorption isotherms of cucumber seeds: Modeling and thermodynamic properties. Journal of Seed Science 37(3):218-225. DOI: https://doi.org/10.1590/23171545v37n3149549

Corrêa PC, Baptestini FM, Bustos-Vanegas JD, Leite R, Botelho FM, Oliveira GHH de (2017) Kinetics of water sorption of damaged bean grains: Thermodynamic properties. Revista Brasileira de Engenharia Agrícola e Ambiental 21(8):556-561. DOI:

http://doi.org/10.1590/1807-1929/agriambi.v21n8p556-561

Costa LM, Resende O, Oliveira DEC de (2013) Isotermas de dessorção e calor isostérico dos frutos de crambe. Revista Brasileira de Engenharia Agrícola e Ambiental 17(4):412-418. DOI: http://doi.org/10.1590/S141543662013000400009

Costa JMG, Silva EK, Hijo AACT, Azevedo VM, Borges SV (2015) Physical and thermal stability of spray-dried swiss cheese bioaroma powder. Drying Technology 33(3):346-354.

Draper NR, Smith H (1998) Applied regression analysis. New York, John Wiley \& Sons, 3 ed. 712 p.

Goneli ALD, Corrêa PC, Oliveira GHH de, Gomes CF, Botelho FM (2010) Water sorption isotherms and thermodynamic properties of pearl millet grain. International Journal of Food Science \& Technology 45(4):828-838. DOI: https://doi.org/10.1111/j.13652621.2010.02208.x

Goneli ALD, Corrêa PC, Oliveira GHH de, Afonso Júnior PC (2013) Water sorption properties of coffee fruits, pulped and green coffee. LWT - Food Science and Technology 50(2):386-391. DOI: https://doi.org/10.1016/j.1wt.2012.09.006

Goneli ALD, Corrêa PC, Oliveira GHH de, Resende O, Mauad M (2016) Moisture sorption isotherms of castor beans. Part 1: Mathematical modeling and hysteresis. Revista Brasileira de Engenharia Agrícola e Ambiental 20(8):751-756. DOI: http://doi.org/10.1590/18071929/agriambi.v20n8p751-756 
Hassini L, Bettaieba E, Desmorieuxb H, Torresc SS, Touild A (2015) Desorption isotherms and thermodynamic properties of prickly pear seeds. Industrial Crops and Products 67:457-465. DOI:

https://doi.org/10.1016/j.indcrop.2015.01.078

Iglesias H, Chirife J (1976) Prediction of the effect of temperature on water sorption isotherms of food material. Journal of Food Technology (11):109-116.

James LEA (2009) Quinoa (Chenopodium quinoa Willd.): composition, chemistry, nutritional, and functional properties. Advances in Food and Nutrition Research 58:131. DOI: https://doi.org/10.1016/S1043-4526(09)58001-1

Kaleemullah S, Kailappan R (2007) Monolayer moisture, free energy change and fractionation of bound water of red chillies. Journal of Stored Products Research 43(2):104110. DOI: https://doi. org/10.1016/j.jspr.2005.12.001

Kashaninejad M, Mortazavi A, Safekordi A, Tabil L G (2007) Thin-layer drying characteristics and modeling of pistachio nuts, Journal of Food Engineering 78(1):98-108. DOI: https://doi.org/10.1016/j.jfoodeng.2005.09.007

Koua BK, Koffi PM, Gbaha P, Toure S (2014)

Thermodynamic analysis of sorption isotherms of cassava (Manihot esculenta). Journal of Food Science and Technology 51(9):1711-1723. DOI: https://doi.org/10.1007/s13197-012-0687-y

Lahsasni S, Kouhila M, Mahrouz M (2004) Adsorptiondesorption isotherms and heat of sorption of prickly pear fruit (Opuntia ficus indica). Energy Conversion and Management 45(2):249-261. DOI: https://doi.org/10.1016/S0196-8904(03)00133-X

Madamba PS, Driscoll RH, Buckle KA (1996) Enthalpyentropy compensation models for sorption and browning of garlic. Journal of Food Engineering 28(2):109-119. DOI: https://doi. org/10.1016/0260-8774(94)00072-7

Oliveira DEC de, Resende O, Chaves TH, Souza KA, Smaniotto TA de S (2014) Propriedades termodinâmicas das sementes de pinhão-manso. Bioscience Journal 30(3):147-157.

Oswin CR (1946) The kinetic of package life. III Isotherm. Journal of Chemical Industry 65:419-421.

Palipane KB, Driscoll RH (1992) Moisture sorption characteristics of in-shell macadamia nuts. Journal of Food Engineering 18(1):63-76. DOI:

https://doi.org/10.1016/0260-8774(93)90075-U

Resende O, Corrêa PC, Goneli ALD, Ribeiro DM (2006) Isotermas e calor isostérico de sorção do feijão. Revista Ciência e Tecnologia de Alimentos 26(3):626-631. DOI: https://doi.org/10.1590/ S0101-20612006000300022

Resende O, Oliveira DEC de, Chaves TH, Ferreira J, Bessa V (2014) Kinetics and thermodynamic properties of the drying process of sorghum (Sorghum bicolor [L.] Moench) grains. African Journal of Agricultural Research 9(32):2453-2462. DOI:

https://doi.org/10.5897/AJAR2014.8808
Siqueira VC, Resende O, Chaves TH (2012) Propriedades físicas das sementes de pinhão-manso ao longo da secagem em diferentes temperaturas. Semina: Ciências Agrárias 33(1):2705-2714. DOI:

https://doi.org/10.5433/1679-0359.2012v33Sup11p2705

Solomon WK, Zewdu AD (2016) Thermodynamic properties of moisture adsorption in tef (eragrostis tef) seed. Engineering in Agriculture, Environment and Food 9(4):339-345. DOI:

https://doi.org/10.1016/j.eaef.2016.05.001

Sormoli M, Langrish T (2015) Moisture sorption isotherms and net isosteric heat of sorption for spray-dried pure orange juice powder. LWT - Food Science Technology 62(1):875-882. DOI:

https://doi.org/10.1016/j.lwt.2014.09.064

Smaniotto TAS, Resende O, Oliveira DEC de, Sousa KA de, Campos RC (2012) Isotermas e calor latente de dessorção dos grãos de milho da cultivar AG 7088. Revista Brasileira de Milho e Sorgo 11(3):312-322. DOI: https://doi.org/10.18512/1980-6477/RBMS.V11N3P312322

Spehar CR (2007) Quinoa: alternativa para diversificação agrícola e alimentar. Planaltina, Embrapa Cerrados, 103p.

Sousa KA de, Resende O, Costa LM (2013) Isotermas de dessorção das sementes de nabo forrageiro obtidas pelos métodos dinâmico e estático. Revista Brasileira de Engenharia Agrícola e Ambiental 17(2):216-222. DOI: http://dx.doi.org/10.1590/S1415-43662013000200013

Sousa KA de, Resende O, Goneli ALD, Smaniotto TAS, Oliveira DEC de (2015) Thermodynamic properties of water desorption of forage turnip seeds. Acta Scientiarum Agronomy 37(1):11-19. DOI:

http://doi.org/10.4025/actasciagron.v37i1.19333

Souza SJF de, Alves AI, Vieira ENR, Vieira JAG, Ramos AM, Telis-Romero J (2015) Study of thermodynamic water properties and moisture sorption hysteresis of mango skin. Food Science and Technology 35(1):157-166. DOI: http://doi.org/10.1590/1678-457X.6557

Stikic R, Glamoclija D, Demin M, Vucelic-Radovic B, Jovanovic Z, Milojkovic-Opsenica D, Jacobsen S, Milovanovic M (2012) Agronomical and nutritional evaluation of quinoa seeds (Chenopodium quinoa Willd.) as an ingredient in bread formulations. Journal of Cereal Science 55(2):132-138. DOI:

https://doi.org/10.1016/j.jcs.2011.10.010

Teixeira LP, Andrade ET, Espíndola JZ, Pereira RG (2015) Determinação do equilíbrio higroscópico e do calor isostérico do bagaço de cana-de-açúcar. Journal of the Brazilian Association of Agricultural Engineering 35(3):555-566. DOI: http://dx.doi.org/10.1590/1809-4430Eng.Agric.v35n3p555-566/2015 
Telis-Romero J, Kohayakawa MN, Silveira Júnior V, Pedro MAM, Gabas AL (2005) Enthalpy-entropy compensation based on isotherms of mango. Ciência e Tecnologia de Alimentos 25(2):297-303.

DOI: https://doi.org/10.1590/S0101-20612005000200020

Thompson TL, Peart RM, Foster GH (1968) Mathematical simulation of corn drying - a new model. Transaction of the ASAE 24:582-586.

Vega-Gálvez A, Miranda M, Vergara J, Uribe E, Puente L, Martínez EA (2010) Nutrition facts and functional potential of quinoa (Chenopodium quinoa willd.), an ancient Andean grain: A review. Journal of the Science of Food and Agriculture 90(15):2541-2547. DOI:

https://doi.org/10.1002/jsfa.4158
Velázquez-Gutiérrez SK, Figueira AC, Rodríguez-Huezo ME, Román-Guerrero A, Carrillo-Navas H, Pérez-Alonso C (2015) Sorption isotherms, thermodynamic properties and glass transition temperature of mucilage extracted from chia seeds (Salvia hispanica L.). Carbohydrate Polymers 121:411-419. DOI: https://doi.org/10.1016/j.carbpol.2014.11.068

Zeymer JS, Corrêa PC, Oliveira GHH de, Baptestini FM, Freitas RCP (2017) Desorption isotherms of Lactuca sativa seeds. Revista Brasileira de Engenharia Agrícola e Ambiental 21(8):568-575. DOI:

http://dx.doi.org/10.1590/1807-1929/agriambi.v21n8p568572

Wolf M, Walker JE, Kapsalis JG (1972) Water sorption hysteresis in dehydrated food. Journal of Agricultural Food Chemistry 20(5):1073-1077. DOI:

https://doi.org/10.1021/jf60183a021 